\title{
Effects of dietary lipid levels on growth performance and blood parameters of the African catfish (Clarias gariepinus).
}

\section{Mohamed M. Abdel-Aal}

Central Laboratory for Aquaculture Research, Agricultural Research Center, Abbassa, Abo-Hammad, Sharkia, Egypt.

\section{ABSTRACT}

The African catfish (Clarias gariepinus) fed on diets containing different 1 lipid levels $(5 \%, 10 \%, 15 \%$ and $20 \%)$ at a feeding rate of $3 \%$ of the live body weight. Fish were reared in glass aquaria at a stocking rate of 10 fish at each aquarium. Each dietary lipid level was presented in triplicates. The trial lasted for 90 days from the start. Ten fish were distributed in $100-\mathrm{L}$ glass aquaria. Fish fed daily for 90 days in triplicate form.

Results revealed that fish growth parameters as a final weight, weight gain, and specific growth rate were generally increased by increasing dietary lipid levels up to $10 \%$, after which the growth rate was markedly decreased. Differences in feed intake among different treatments varied significantly $(\mathrm{P}<0.05)$. Feed conversion ratio (FCR) was affected by dietary levels of lipids. No significant changes in survival rate were observed due to the variation in dietary lipid levels. The highest values of the erythrocyte count (RBCS), hemoglobin content $(\mathrm{Hb})$ and packed cell volume (PCV) were obtained in fish group fed on the diet containing $15 \%$ and $20 \%$ lipid. Furthermore, mean corpuscular value (MCV), mean corpuscular hemoglobin ( $\mathrm{MCH}$ ) and mean corpuscular hemoglobin concentration (MCHC) were changed in blood of fish fed on different levels of lipid. Glucose, total lipids, and total protein were significantly affected by increasing the lipid levels. Plasma total lipids and total protein were increased in fish with increasing lipid levels in the diets, Also, plasma AST and ALT activities increased significantly with increasing the level of lipids in fish diets, reaching the highest value in fish group fed diet with $20 \%$ lipids. The hepato-somatic index and gonado-somatic index of African catfish were significantly increased with increasing lipid level in fish diets. The present study demonstrated that the optimum dietary lipid level was $10 \%$ for African catfish and there was no observed beneficial effect when fish was fed a diet containing $15 \%$ or $20 \%$ lipid levels.

Keywords: African catfish, dietary lipids, growth performance, hematological parameters. 


\section{INTRODUCTION}

Dietary lipids play an important role in commercial diets as a source of energy and essential fatty acids for the growth and development of fishes (NRC, 1993). Moreover, it could also spare dietary protein from use as energy and limit ammonia production (Arzel et al., 1994; Chou and Shiau, 1996; Kim and Lee, 2005).

The low inclusion of dietary lipids could lead to the consumption of protein for energy requirements. On the other hand, high dietary lipid content might decrease feed consumption and reduce growth (Ahamad, 2004; Pei et al., 2004; El-Marakby, 2006; Abbass, 2007). Therefore, it is important, from nutritional and economical points of view, to improve protein utilization for tissue synthesis rather than for energy purposes. The increase in dietary lipid improved protein utilization in brown trout (Gabaudan et al., 1989) as in many other fish (Lee and Putnam, 1973; Alliot et al, 1979; Cho and Kaushik, 1990).

The African catfish (Clarias gariepinus) due to its tolerance to a wide range of temperatures, low oxygen and high salinity levels, fast fecundity and growth rate is therefore considered as a candidate of freshwater fish for aquaculture (Hecht et al., 1996; Otémé et al., 1996). Moreover, this fish has high nutritive value, good taste, and fewer bones. The optimal dietary lipid levels have to be carefully evaluated and determined for this fish. Therefore, this study was conducted to determine the effect of different lipid levels (5-20\%) on growth performance of the African catfish (C. gariepinus).

\section{MATERIALS AND METHODS}

Fish rearing conditions:

This study was carried out at the Central Laboratory for Aquaculture Research, Abbassa, Abou-Hammad, Sharkia Governorate, Egypt. The African catfish (C. garpinus) was obtained from a private hatchery, at Abbassa, AbouHammad, Sharkia Governorate. Fish were kept in an indoor tank separately for two weeks for acclimatization. The average range of fish weight was 52.2 to $53.55 \mathrm{~g}$. Fish were fed on a commercial diet during the preliminary period. Fifty fish were stored in a refrigerator at $-5^{\circ} \mathrm{C}$ for proximate chemical analysis. Fish were graded and randomly distributed into glass aquaria at a rate of 10 fish per 100-L aquarium ( $75 \times 40 \times 50 \mathrm{~cm}, \mathrm{~L} \times \mathrm{W} \times \mathrm{H})$ contained well-aerated and dechlorinated tap water, which was stored overnight in cylindrical fiberglass tanks. Aquaria were supplied with compressed air from air pumps via air stones. The water temperature was $21^{\circ} \mathrm{C}$ for first month and was adjusted at $26.0 \pm 2.0^{\circ} \mathrm{C}$ by thermostatically controlled column heaters. Fish in each aquarium were handfed at a rate of $3 \%$ of live body weight twice daily for 90 days. Fish faeces and uneaten feed were removed daily by siphoning and the half of water volume from each aquarium was removed and replaced by well-aerated tap water. Fish 
in each aquarium was weighed biweekly and subsequently the amount of the given feed was readjusted accordingly. At the end of the experiment, fish were harvested, counted and weighed. Five fish from each treatment were stored in a refrigerator at $-5^{\circ}$ for proximate chemical analysis. The different parameters of fish growth and feed utilization were calculated as described by Almad et al. (2004). Each lipid level tested was represented in three aquaria (triplicates) i.e. 12 aquaria each contained 10 experimental fish.

\section{Experimental diets:}

Four isonitrogenous diets ( $35 \%$ crude protein) were formulated to contain graded levels of fish oils and corn oil mixture (1:1) to obtain total crude lipid levels of $5 \%, 10 \%, 15 \%$ or $20 \%$. Feed ingredients were ground into fine powder in a Thomas-Wiley Laboratory Mill (Model 4, USA). After sieving, the fine powder ingredients were thoroughly mixed with the oils mixture, and $40 \%$ water was added to produce clump dough. The dough was then pelleted through a die of Spaghetti Machine (La Parmigiana, Model D45 LE, Italy) and dried at room temperature. After drying, the diets were broken up and sieved into proper pellet size ( $2 \mathrm{~mm}$ diameter). Diets were transferred to dark plastic bags and stored in a refrigerator at $-5^{\circ} \mathrm{C}$ until used. Composition of the experimental diets and its chemical analysis are represented in Table (1).

Table (i). Ingredients and nutrients composition of the experimental diets.

\begin{tabular}{|c|c|c|c|c|}
\hline \multirow{2}{*}{ Items } & \multicolumn{4}{|c|}{ Lipid levels } \\
\hline & $5 \%$ & $10 \%$ & $15 \%$ & $20 \%$ \\
\hline Fish meal $(72 \% \mathrm{CP})$ & 20.5 & 20.5 & 20.5 & 20.5 \\
\hline Soybean meal $(44 \% \mathrm{CP})$ & 40.0 & 40.0 & 40.0 & 42.0 \\
\hline Wheat bran $(16.4 \% \mathrm{CP})$ & 5.0 & 5.0 & 5.0 & 5.0 \\
\hline Yellow corn $(8.5 \% \mathrm{CP})$ & 27.0 & 22.0 & 17.0 & 10.0 \\
\hline Fish and oil $(1: 1)$ & 5.0 & 10.0 & 15.0 & 20.0 \\
\hline Vitamin \& Mineral Premix & 1.5 & 1.5 & 1.5 & 1.5 \\
\hline Carboxymethyl cellulose & 1.0 & 1.0 & 1.0 & 1.0 \\
\hline Total & 100 & 100 & 100 & 100 \\
\hline \multicolumn{5}{|l|}{ Proximate analysis $\{\%\}$} \\
\hline Dry matter & 92.03 & 91.75 & 92.15 & 92.11 \\
\hline Crude protein & 35.00 & 34.98 & $35.1 \overline{3}$ & 34.91 \\
\hline Ether extract & 9.52 & 14.33 & 19.22 & 24.12 \\
\hline Crude fiber & 4.89 & 4.82 & 5.00 & 5.13 \\
\hline Nitrogen free extract ${ }^{b}$ & 42.99 & 38.36 & $3 \overline{3: 30}$ & 28.37 \\
\hline Ash & 7.60 & 7.51 & 7.35 & 7.47 \\
\hline
\end{tabular}

- Same as Lee et al. (2000).

b Nitrogen free extract was calculated by difference (100-crude protein-crude lipidcrude ash-crude fiber). 
Proximate chemical analysis:

Fish, feed and feces were ground and analyzed in triplicate samples according the standard methods of AOAC (1990). Moisture content was determined by oven drying at $65^{\circ} \mathrm{C}$ for 24 hours and $105^{\circ} \mathrm{C}$ till a constant weight was obtained. Crude protein $(\mathrm{N} \times 6.25)$ was determined by micro-Kjeldahl method. Total crude lipid was determined by Soxthlet extractor using petroleum ether for 16 hours. Ash by combustion at $550^{\circ} \mathrm{C}$. Crude fiber was estimated according to Goering and Van Soest (1970). Nitrogen-Free Extract (NFE) calculated by difference. Gross energy of experimental diets was estimated according to NRC (1993).

Blood Analysis:

At the end of experiment, blood samples were taken from caudal vein of an anaesthetized fish by sterile syringe using EDTA solution as an anticoagulant. These blood samples were used for determining erythrocyte count (Dacie and Lewis 1984), hemoglobin content (Van Kampen and Zijlstra, 1961), and haematocrite value (Britton, 1963). Plasma was obtained by centrifugation at $3000 \mathrm{rpm}$ for $15 \mathrm{~min}$ and unhaemolyzed plasma was stored in deep freezer for further biochemical analyses. Glucose was determined, using glucose kits supplied by Boebring Mannheium kit, according to Trinder (1969). Total protein content was determined colorimetrically according to Henry (1964). Total lipids contents were determined colorimetrically according to Joseph et al. (1972).

Statistical analysis:

The obtained data were statistically analyzed by completely randomized design according to Snedecor and Cochran,(1994). Differences between treatments were statistical tested by Duncan's multiple range test (Duncan, 1955).

The growth performance:

\section{RESULTS}

The growth performance parameters were affected by lipid levels as shown in Table (2). The best growth performance of African catfish was attained when fish were fed on diet contained $10 \%$ total lipid. The least growth was found in fish fed the diet contained $20 \%$ lipid. Fish growth parameters as a finial weight, weight gain, and specific growth rate were generally increased by increasing dietary lipid levels up to $10 \%$ after which the growth rate was markedly decreased. Differences in feed intake among different treatments differed significantly $(\mathrm{P}<0.05)$. Feed conversion ratio $(\mathrm{FCR})$ was affected by dietary levels of lipids. The best (lowest) FCR was achieved when fish fed $10 \%$ (2.79) and the worst value was obtained using the diet containing $20 \%(4.35)$. While there was no difference $(\mathrm{P}<0.05)$ with regard to the survival rates among treatments, the dietary level containing $20 \%$ lipid came significantly different $(\mathrm{P}<0.05)$ compared to the $10 \%$ and $15 \%$ lipid levels with regard to SGR and FCR. 
Table (2): Growth performance parameters of African catfish as affected with different dietary lipid levels.

\begin{tabular}{|c|c|c|c|c|}
\hline \multirow[b]{2}{*}{ Items } & \multicolumn{4}{|c|}{ Dietary lipid levels } \\
\hline & $5 \%$ & $10 \%$ & $15 \%$ & $20 \%$ \\
\hline $\begin{array}{l}\text { Initial weight } \\
\text { (g/fish) }\end{array}$ & $53.55 \pm 0.98^{3}$ & $52.55 \pm 1.28^{n}$ & $52.55 \pm 1.36^{2}$ & $52.2 \pm 1.55^{\prime}$ \\
\hline $\begin{array}{l}\text { Final weight } \\
(\mathrm{g} / \text { fish })\end{array}$ & $73.5 \pm 2.02^{6}$ & $78.5 \pm 1.46^{\star}$ & $75.00 \pm 2.12^{2}$ & $70.00 \pm 1.28^{6}$ \\
\hline Weight gain (g/fish) & $19.95 \pm 0.38^{5}$ & $25.9 \pm 0.64^{2}$ & $22.4 \pm 0.42^{2}$ & $17.8 \pm 0.56^{6}$ \\
\hline $\operatorname{SGR}(\% /$ day $)$ & $0.352 \pm 0.02^{35}$ & $0.446 \pm 0.02^{2}$ & $0.395 \pm 0.03^{3}$ & $0.325 \pm 0.03^{8}$ \\
\hline $\begin{array}{l}\text { Feed intake (g } \\
\text { feed/fish) }\end{array}$ & $78.00 \pm 3.5 b^{7}$ & $72.50 \pm 6.5^{8}$ & $74.81 \pm 5.4^{2}$ & $77.50 \pm 7.2^{6}$ \\
\hline ECR & $3.909 \pm 0.35^{c}$ & $2.799 \pm 0.24^{4}$ & $3.339 \pm 0.32^{6}$ & $4.353 \pm 0.36^{\circ}$ \\
\hline Survival ratc $(\%)$ & $90 \pm 2.5^{3}$ & $100 \pm 0.0^{\mathrm{a}}$ & $100 \pm 0.0^{8}$ & $100 \pm 0.0^{4}$ \\
\hline
\end{tabular}

The same letter in the row is not significantly different at $\mathrm{p}<0.05$.

\section{Hematological parameters:}

The erythrocyte count (RBCS), hemoglobin content ( $\mathbf{H b}$ ) and packed cell volume (PCV) in the blood of African catfish were significantly affected with deferent levels of lipid in the tested diets (Table 3). The highest values of these parameters were obtained in fish group fed a diet with $15 \%$ and $20 \%$ lipid levels. Furthermore, blood indices; mean corpuscular value (MCV), mean corpuscular hemoglobin (MCH) and mean corpuscular hemoglobin concentration (MCHC) were changed in blood of fish fed on different dietary levels of lipid according to the changes occurred in the blood parameters.

Results of the chemical composition of plasma are shown in Table (4). Glucose was significantly affected by increasing the lipid levels $(\mathrm{P}<0.05)$. Also, the total lipids were increased in fish fed 10,15 and 20\% lipid diet (25.649, $26.93 \& 31.8 \mathrm{~g} / \mathrm{l}$, respectively). Also, plasma total protein was increased significantly with increasing lipid levels in the diets. Moreover, the obtained results showed that plasma AST and ALT activities increased significantly with increasing the level of lipids in the fish diet, reaching the highest value in fish group fed diet with $20 \%$ lipids. The hepato-somatic index and gonado-somatic index of African catfish (Table 5) were significantly increased with increasing lipid level in fish diets $(\mathrm{P}<0.05)$. 
Table (3): Changes in erythrocyte count (RBCs), hemoglobin (Hb) content, packed cell volume (PCV), mean corpuscular volume (MCV), mean corpuscular hemoglobin (MCH) and mean corpuscular hemoglobin concentration (MCHC) in the blood of African catfish fed different dietary lipid levels.

\begin{tabular}{|l|c|c|c|c|}
\hline \multirow{2}{*}{ Jtems } & \multicolumn{4}{|c|}{ Dietary lipid levels } \\
\cline { 2 - 5 } & $5 \%$ & $10 \%$ & $15 \%$ & $20 \%$ \\
\hline $\mathrm{RBCs}\left(\times 10^{\mathrm{b}} / \mathrm{ml}\right)$ & $2.33 \pm 0 . \mathrm{I}^{\mathrm{b}}$ & $2.56 \pm 0.07^{\mathrm{b}}$ & $3.15 \pm 0.14^{\mathrm{a}}$ & $2.62 \pm 0.05^{\mathrm{b}}$ \\
\hline $\mathrm{Hb}(\mathrm{g} / 100 \mathrm{ml})$ & $6.54 \pm 0.34^{\mathrm{d}}$ & $7.49 \pm 0.43^{\mathrm{c}}$ & $9.11 \pm 0.49^{\mathrm{a}}$ & $8.18 \pm 0.41^{\mathrm{b}}$ \\
\hline $\mathrm{PCV}(\%)$ & $23.6 \pm 0.60^{\mathrm{b}}$ & $24.0 \pm 1.06^{\mathrm{b}}$ & $28.2 \pm 1.17^{\mathrm{a}}$ & $23.3 \pm 0.96^{\mathrm{b}}$ \\
\hline $\mathrm{MCV}$ & $93.9 \pm 1.38^{\mathrm{c}}$ & $102.6 \pm 2.65^{\mathrm{b}}$ & $107.9 \pm 4.13^{\mathrm{a}}$ & $73.6 \pm 2.35^{\mathrm{d}}$ \\
\hline $\mathrm{MCH}(\mathrm{pg})$ & $29.3 \pm 0.75^{\mathrm{b}}$ & $28.1 \pm 0.92^{\mathrm{b}}$ & $31.4 \pm 1.02^{\mathrm{a}}$ & $29.3 \pm 1.01^{\mathrm{b}}$ \\
\hline $\mathrm{MCHC}(\%)$ & $31.4 \pm 1.05^{\mathrm{b}}$ & $29.7 \pm 1.08^{\mathrm{c}}$ & $39.3 \pm 1.22^{\mathrm{a}}$ & $29.9 \pm 0.81^{\mathrm{c}}$ \\
\hline
\end{tabular}

The same letter in the row is not significantly different at $\mathrm{p}<0.05$.

Table (4): Changes of glucose, total protein, total lipid, aspartate aminotransferas (AST) and alanine aminotransferase (ALT) in plasma of African catfish fed different dietary lipid levels.

\begin{tabular}{|l|c|c|c|c|}
\hline \multirow{2}{*}{ Items } & \multicolumn{4}{|c|}{ Dietary lipid levels } \\
\cline { 2 - 5 } & $5 \%$ & $10 \%$ & $15 \%$ & $20 \%$ \\
\hline Glucose (mg/dl) & $73.4 \pm 2.09^{\mathrm{d}}$ & $108.4 \pm 4.51^{\mathrm{c}}$ & $280.7 \pm 14.63^{\mathrm{a}}$ & $249.5 \pm 18.58^{\mathrm{b}}$ \\
\hline Total protein (mg/dl) & $4.38 \pm 0.38^{\mathrm{b}}$ & $4.51 \pm 0.32^{\mathrm{b}}$ & $5.61 \pm 0.19^{\mathrm{c}}$ & $5.16 \pm 0.39^{\circ}$ \\
\hline Total lipid (g/l) & $21.44 \pm 0.79^{\mathrm{c}}$ & $25.65 \pm 1.32^{\mathrm{b}}$ & $26.92 \pm 1.33^{\mathrm{b}}$ & $31.82 \pm 2.43^{2}$ \\
\hline AST (IU/l) & $14.90 \pm 1.24^{\mathrm{c}}$ & $14.86 \pm 0.55^{\mathrm{c}}$ & $30.52 \pm 1.35^{\mathrm{b}}$ & $32.20 \pm 1.352^{\mathrm{z}}$ \\
\hline ALT(IU/I) & $6.70 \pm 1.10^{\mathrm{b}}$ & $6.57 \pm 0.58^{\mathrm{b}}$ & $7.808 \pm 0.63^{\mathrm{a}}$ & $7.81 \pm 0.46^{\circ}$ \\
\hline
\end{tabular}

The same letter in the row is not significantly different at $p<0.05$.

Table (5): Change of hepatosomatic index (HSF) and gonadosomatic index (GSI) of African catfish fed different dietary lipid levels.

\begin{tabular}{|c|c|c|c|c|}
\hline \multirow{2}{*}{ Items } & \multicolumn{4}{|c|}{ Dietary lipid levels } \\
\cline { 2 - 5 } & $5 \%$ & $10 \%$ & $15 \%$ & $20 \%$ \\
\hline HSI (\%) & $0.736 \pm 0.075^{\mathrm{b}}$ & $0.789 \pm 0.045^{\mathrm{b}}$ & $0.798 \pm 0.074^{\mathrm{b}}$ & $1.648 \pm 0.133^{\mathrm{Z}}$ \\
\hline GSI (\%) $\delta^{7}$ & $0.74 \pm 0.03^{\mathrm{b}}$ & $0.817 \pm 0.046^{\mathrm{a}}$ & $0.955 \pm 0.104^{\mathrm{a}}$ & $0.870 \pm 0.057^{\mathrm{2}}$ \\
\hline GSI (\%) $\%$ & $12.617 \pm 1.79^{\mathrm{C}}$ & $12.405 \pm 2.383^{\mathrm{c}}$ & $14.945 \pm 1.342^{\mathrm{b}}$ & $20.54 \pm 0.377^{\mathrm{z}}$ \\
\hline
\end{tabular}

The same letter in the row is not significantly different at $\mathrm{p}<0.05$. 


\section{DISCUSSION}

The growth performance of the African catfish was improved with the gradual increase in dietary lipid levels from $5 \%$ to $10 \%$, while the least fish growth values were achieved in fish fed on diet containing $20 \%$ lipid. The lowest fish growth obtained when fish fed diet containing excess lipid may be due to the imbalance of protein/energy ratio and/or reduced feed consumption. These results are in agreement with that reported by Lee et al, (2000) who showed a significant decrease from $7 \%$ to $16 \%$ in weight gain. Almost the same trend was found by Oku and Ogata, (2000) who reported $10.5 \%$ to $20 \%$ growth rate decrease as well as what has been reported by Alam et al., (2003) reporting a reduction of $10 \%$ to $20 \%$ of growth rate. Also, Watanabe et al. (2001) found similar resuits with turbo, Scophalmus maximus and mutton snapper, Lutjanus analis. Cho and Watanabe (1988) showed that the increase of energy retention and the formation of new tissues promote a progressive increase in fish weight. The weight gain of young fish is usually a reliable indicator of the nutritional adequacy of diet. Anwar and Jafri (1995) reported that feed conversion, protein efficiency ratio and muscle protein deposition were higher and comparable in fish fed 7 and $9 \%$ lipid diet. Also, Martino et al. (2002) reported that the diet with $6 \%$ lipid gave the poorest performance, while fish fed the highest lipid level (18\%) showed the best nutritional performance. Feed conversion ratio and daily feed consumption showed a marked decrease $(\mathrm{P}<0.05)$ (improvement) in inverse proportion to lipid levels in the diet.

The utility of hematology in assessing fish health and as an aid to fish disease diagnosis has been questioned. In this study, $\mathrm{RBCs}, \mathrm{Hb}$ and $\mathrm{PCV}$ were were significantly affected by different lipid levels. Klinger $e t$ al. (1996) reported that $\mathrm{RBCs}$ are the cells most affected by dietary manipulations. As a particular fish acclimates to a lower temperature, more highly unsaturated fatty acids are incorporated into the phospholipids protein of the membrane. This is true for blood cells (Lie et al., 1989) and other cells (Dey et al., 1993).

The difference in lipid requirement among the different studies are existed due to the differences in many factors such as diet formulation and composition, feeding strategy, fish size, water quality and culture system (Lin et al., 1997). The calculated blood indices i.e. $\mathrm{MCH}, \mathrm{MCHC}$ and $\mathrm{MCV}$ have a particular importance in describing anemia in most animals (Coles, 1986). The disturbances occurred in these indices are related to those occurred in $\mathrm{RBCs}, \mathrm{Hb}$ and PCV due to the exaggerated disturbances that occurred in both metabolic and hemopoietic activities of fish. The obtained results showed that the plasma AST and ALT activities increased significantly with increasing the lipid levels. The same trend was recorded in glucose, total protein and total lipids. These results are in agreement with Gallagher (1999) who demonstrated that liver ALT activity increased in the liver of sunshine bass as protein level increase or when lipid replaced dextrin in the diet. The increase in enzyme activity corresponded to an increase in liver lipid content. However, if too much lipid is provided in the 
diet weight gain may actually decreased (Watanabe, 1982). Furthermore, it has been well demonstrated that too much dietary lipid may promote an undesirable increase in body lipid content causing many health problems (Klinger et al., 1996).

\section{ACKNOWLEDGMENTS}

The author would like to thank Prof. Dr. Adel M.E. Shalaby, Central Laboratory for Aquaculture Research, Abbassa, Abu-Hammad, Sharkia, Egypt for his help in carrying out the blood analyses.

\section{REFERENCES}

Abbass, F.E. (2007). Effect of dietary oil sources and levels on growth, feed utilization and whole-body chemical composition of common carp, Cyprinus carpio L. fingerlings. Journal of Fisheries and Aquatic Sciences, 2(2): 140-148.

Ahamad, A. S. (2004). Evaluation of different sources of lipid and lipid levels in the diet of pearlspot Etroplus suratensis (Teleostei : Perciformes). Indian Journal of Marine Sciences, 33(3): 281-286.

Ahmad, M.A.; Abdel-Tawwab, M. and Khattab, Y.A.E. (2004). Effect of dietary protein levels on growth performance and protein utilization in Nile tilapia (Oreochromus niloticus) with different initial body weights. Proceedings of the sixth International Symposium on Tilapia in Aquaculture, 14-16 September 2004, Manila, Philippines, pp.249-263.

Alam, M.S.; Teshima.S; Koshio.S; Uyan,O. and Ishikawa,M. (2003). Effect of dietary protein and lipid levels on growth and body composition of juvenile Japanese flounder, Paralichthys olivaceus, fed diets containing intact protein or crystalline amino acids. J. of Appl. Aquacul., 14: 115131.

Alliot, E.; Pastoureaud, A. and Nedellec,J. (1979). I apport caloriqe et du rapport caloric-azote dans $\mathrm{J}$ alimentation du bar Dicentrarchus labrax.Influence sur la croissance et al composition corporelle. In : Halver, J.E. and Tiews, K. (Eds.), Proc. World symp. on finfish nutrition and fish feed technology, Hamburg, Germany Heenemann, Berlin, 1: 241-255.

Anwar, M.F and Jafri, A.K. (1995). Effect of dietary lipid levels on growth, feed conversion and muscle composition of the walking Catfish Clarias batrachus. Fish Nutr. Res. Lab. Aligarh Muslim Univ. Aligarh 202002. India. 
AOAC (1990). Official Methods of Analyses of the Association of Official Analytical Chemists International. $15^{\text {th }}$ edition, Arlington, VA, USA.

Arzel, J.; Martinez López, F.X.; Métailler, R.; Stéphan,G.; Viau,M.; Gandemer,G. and Guillaume,J. (1994). Effect of dietary lipid on growth performance and body composition of brown trout (Salmo trutia) reared in seawater. Aquacul., 123: 361-375.

Britton, C.J. (1963). Disorders of the Blood. The $9^{\text {th }}$ ed., I.A. Churrchill, Ltd., London.

Cho, C.Y. and Kaushik,S.J. (1990). Nutritional energetic in fish: protein and energy utilization in rainbow trout. In Bourne-.H. (Ed.),Aspects of food production, consumption and energy values. World Rev. Anim. Nutr., 16: 132-172.

Cho, and Watanabe, (1988).Nutritional energetics. In:Watanbe,T.(ED.),Fish Nutrition and Mariculture. Department of Aquatic Biosciences. Tokyo University of Fisheries, Tokyo, pp.79-95.

Chou, B.S. and S.Y. Shiau (1996). Optimal dietary lipid level for growth juvenile hybrid tilapia, Oreachromis niloticus $\mathrm{x}$ Oreochromis aureus. Aquacul., 143: 185-195.

Coles,E.H.(1986).Veterinary Clinical Pathology. W.B. Saunders, Philadelphia,pp.10-42.

Dacie, J.V. and Lewis, S.M. (1984). Pratical Haematology. Churchill Living Stone, London.

Dey, I.; Buda, C.; Wiik, T.; Halver, J. and Farkas, T. (1993). Molecular and structural composition of phospholipids membranes in livers of marine and freshwater fish in relation to temperature. Pros. Natl. Acad. Sci. USA, 90: 7498-7520.

Duncan, D.B. (1955). Multiple range and multiple F-test. Biometrics, 11: 1-42.

El-Marakby, H.I. (2006). The effect of dietary lipid source and level on growth, feed utilization and body chemical composition of fry Nile tilapia, Oreochromis niloticus (L.) (Teleostei : Perciforms). Journal of Fisheries and Aqu. Sci., 1(2): 117-125.

Gabaudan, J.; Metailler, R. and Guillaume, J. (1989). Nutrition compare de la truite arc en ciel (Oncorhynchus mykiss), la truite fario (Salmo trulla) et 
le salmon cohon (Oncorhynchus kistutch). Effect des taux de protein totals et de lipids. ICES, 5: 1-13.

Gallagher, M.L. (1999). Growth responses, tissue composition, and liver enzyme changes in Juvenile sunshine bass, Morone chrysops x M.saxatilis, associated with dietary protein and lipid level. Journal of applied Aquaculture, 9(4): 4l-51.

Goering: H. K. and Van Soest, P.G. (1970). Forage fiber analysis. Apparatus 1368- 1375.

Hecht, T:; Oellermann, L. and Verheust,L. (1996). Perspectives on clariid catfish culture in Africa. Aquatic Living Resources 9: 197-206 (Hors série).

Henry, R.J. (1964). Colorimetric determination of total protein. In: Clinical Chemistry. Harper and Row Publ., New York, 181 pp.

Joseph, A.; Knight,M.; Anderson,S.; James,M. and Rawie,H. (1972). Chemical basis of the sulfophospho-vanillin reaction for estimating total serum lipid. Clin. Chem., 18(3): 198-201.

Kim, L.O. and Lee,S.M. (2005). Effects of the dietary protein and lipid levels on growth and body composition of bagrid catfish,

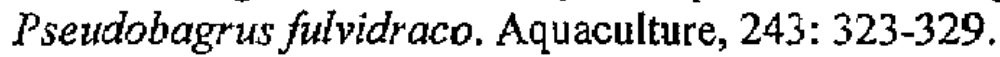

Klinger, R.C.; Blazer,V.S.and Echevarria,C. (1996). Effects of dietary lipid on the hematology of channel catfish, Ictalurus punciatus. Aquaculture, 147: 225-233.

Lee, D.J.and Putnam, G.B. (1973). The response of rainbow trout to varying protein/energy ratios in a test diet. J. Nurt., 103: 916-922.

Lee, S.M.;Cho,S.H. and Kim,K.D. (2000). Effect of dietary protein and energy levels on growth and body composition of juvenile Japanese flounder, Paralichthys olivaceus. J.of the Wld. Aqua.Sci. 31: 306-315.

Lie, O.; Lied, E. and Lambersten, G. (1989). Haematological values and fatty acid composition of erythrocyte phospholipids in cod (Gadus morhua) fed at different water temperatures. Aquaculture, 79: 137-144.

Lin, J.H.; Cui,Y.; Humg,S.S.O. and Shiau,S.Y. (1997). Effect of feeding strategy and carbohydrate source on carbohydrate utilization by white 
sturgeon (Acipenser transmontanus) and hyprid tilapia (Oreochromius niloticus $\times$ O.aureus). Aquaculture, 148:201-211.

Martino, R.C.; Eurico,J.; Cyrino,P.; Portz,L. and Trugo,L.C. (2002). Effect of dietary lipid level on nutritional performance of the surubim, Pseudoplatystoma corwscans. Aquaculture, 209-218

NRC (National Research Council)(1993). Nutrient Requirements of Fish. National Research council, National Academy Press, Washington, D.C., ppl15.

Oku, H. and Ogata,H. (2000). Body lipid deposition in juveniles of red sea bream, Pagrus major,yellowtail,Seriola quinqueradiata and Japanese flounder, Paralichtys olivaceus. Fisheries Science, 66:

Otémé, Z.L.; Hem,S. and Legendre,M. (1996). Nouvelles espèces de poissonschats pour le développement de la pisciculture africaine. Aquatic Living Resources, 9: 207-217 (hors série).

Pei, Z; Xie,S.; Lei,W.; Zhu,X. and Yang,Y. (2004). Comparative study on the effect of dietary lipid level on growth and feed utilization for gibel carp (Carassitus auratus gibelio) and Chinese longsnout catfish (Leiocassis longirostris Günther). Aquaculture Nutrition, 10: 209-216.

Snedecor, G.W. and Cochran,W.G. (1982). Statistical Methods. 6th edition. Iowa State Univ. Press., IA, USA.

Trinder, P. (1969). Determination of glucose concentration in the blood. Ann. Clin. Biochem. 6: 24.

Van Kampen, E.J. and Zijlstra,N.C. (1961). Determination of haemoglobin. Clin. Chem. Acta, 5: 719-720.

Watanabe, O.; Ellis, S. C. and Chaves, J. (2001). Effects of dietary lipid and energy to protein ratio on growth and feed utilization of juvenile mutton sanpper Lutjamus analis fed isonitrogenus diets at low temperature. J. of the Wld. Aqua. Sci., 32: 30-40.

Watanabe, T. (1982). Lipid nutrition in fish. Comp. Biochem. Physiol. 73(B): 315. 